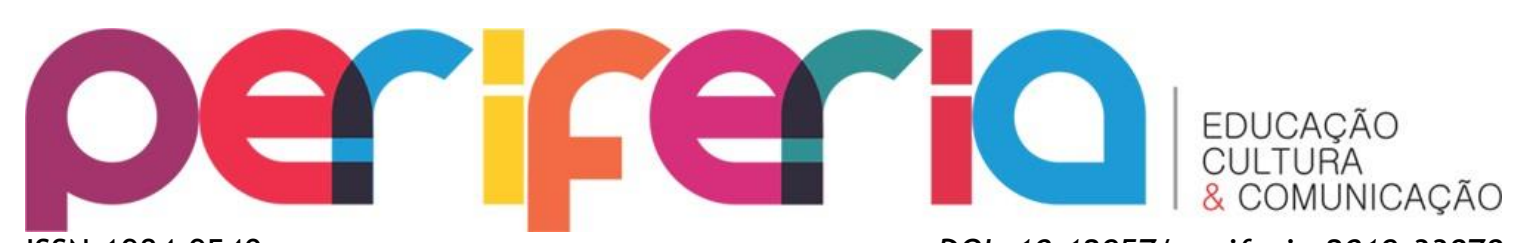

ISSN:1984-9540

DOI: $10.12957 /$ periferia.2019.33878

\title{
MEMES, RACISMO E EDUCAÇÃO, OU POR QUE OS MEMES DA TAIIS ARAÚJO IMPORTAM
}

\author{
Leonardo Fraga Cardoso Junior ${ }^{1}$ \\ Universidade Tiradentes \\ Kaio Eduardo de Jesus Oliveira ${ }^{2}$ \\ Universidade Tiradentes \\ Cristiane de Magalhães Porto ${ }^{3}$ \\ Universidade Tiradentes
}

\section{RESUMO}

Este artigo tem como objetivo discutir a importância dos memes de redes sociais digitais na cibercultura e como eles favorecem a reprodução de discursos racistas na internet. Para isso, tomou-se como objeto o caso dos memes racistas que tencionam o debate sobre racismo a partir da fala da atriz brasileira Taís Araújo em uma edição do TEDx Brasil. A produção de memes articuladas a este caso específico, insere os usuários no debate sobre preconceito social e racial no Brasil a partir de uma fala própria que se expande na rede, especialmente permeada pelo humor e pela sátira de cada meme, mas é ampliada a partir do contexto ético e moral que toma a repercussão. Utiliza-se como método a pesquisa qualitativa, de cunho exploratório e descritivo. Ao final, evidencia-se que os memes racistas presentes nas redes sociais fortalecem o racismo no debate público, visto que ampliam por meio do conteúdo irônico e superficial deste memes propriamente, um discurso que não remete ao sentido original do fato, mas que ganha dimensões hiperbólicas em sentidos distintos na rede e na produção de sentidos e subjetividades dos indivíduos imersos na rede.

Palavras-chave: Educação. Cultura digital. Produção Discursiva.

\footnotetext{
${ }^{1}$ Estudante de graduação do Curso de Comunicação da Universidade Tiradentes - Hab. em Jornalismo. E-mail: leonardofragajr@gmail.com

2 Doutorando em Educação pela Universidade Tiradentes (Bolsista Prosup/Capes). Mestre em Educação (UNIT).

Pesquisador e Vice-líder do Grupo de Pesquisa em Educação, Tecnologias da Informação e Cibercultura (UNIT).

${ }^{3}$ Doutora Multidisciplinar em Cultura e Sociedade - UFBA. Mestrado em Letras e Linguística - UFBA. Pesquisadora do Instituto de Tecnologia e Pesquisa - ITP. Bolsista em Produtividade em Pesquisa do CNPq - Nível 2. Pós-doutorado em Educação - UERJ. É professora do Curso de Comunicação Social e do Programa de Pós-Graduação da Universidade Tiradentes - Unit. Líder do Grupo de Pesquisa Educação, Tecnologia da Informação e Cibercultura (GETIC/UNIT/CNPq).
} 




ISSN:1984-9540

DOI: $10.12957 /$ periferia.2019.33878

\title{
MEMES, RACISM AND EDUCATION, OR WHY THE MEMES ABOUT TAÍS ARAÚJO MATTER
}

\begin{abstract}
This article has a goal to discuss the importance of memes shared through digital social networks in cyberculture and it's contribution to the reproduction of racist content on the internet. For this, it was taken as object, racist memes about the Brazilian actress Taís Araújo that went viral in social networks after her speech at a TEDx event held in Brazil. The memes produced from this specific case inserted several users into a debate about social and racial prejudice in Brazil from a speech that went viral on the internet, specially, because of the humor and satirical message of its content, but it clearly exceeded ethical and moral boundaries. It was used as methodology the qualitative research, exploratory and descriptive. At the end, it was evident that racist content shared through social networks contributes and strengthens racism in the public debate, it occurs by an ironical and superficial message with racist content that was produced with the intention to change the original message. This new content widespread on the web, receiving new meanings and producing new senses and subjectiveness in the social networks users.
\end{abstract}

Keywords: Education. Digital Culture. Discursive Production.

\section{MEMES, RACISMO Y EDUCACIÓN, O POR QUE LOS MEMES DE TAÍS ARAÚJO IMPORTAN}

\section{RESUMEN}

Este artículo tiene como objetivo discutir la importancia de los memes de redes sociales digitales en la cibercultura y como ellos favorecen la reproducción de los discursos racistas en internet. Para eso, tenemos como objeto, el caso de los memes racistas que tensionan el debate a respeto del racismo desde el habla de la actriz brasileña Taís Araújo en una edición del TEDx Brasil. La reproducción de memes articuladas a este caso en específico, inserta los usuarios en el debate a respeto del prejuicio social y racial en Brasil desde un habla que se expande en la red, especialmente permeado por el humor y por la sátira de cada meme, pero es ampliada desde un contexto ético y moral que tiene la repercusión. Se utiliza como método la pesquisa cualitativa, de naturaleza exploratoria y descriptiva. Al fin, se señala que los memes racistas presentes en las redes sociales fortalecen el racismo en el debate público, visto que amplían por medio del contenido irónico y superficial de estos memes propiamente, un discurso que no remete al sentido original de hecho, pero que gana dimensiones hiperbólicas en distintos sentidos en la red y en la producción de sentidos y subjetividades de los individuos inmersos en la red.

Palabras clave: EDUCACIÓN. CULTURA DIGITAL. PRODUCCIÓN DISCURSIVA. 


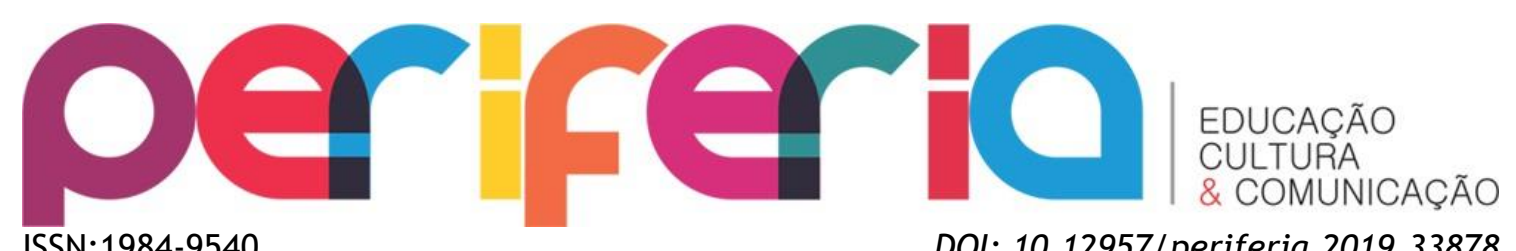

ISSN:1984-9540

DOI: $10.12957 /$ periferia. 2019.33878

\section{INTRODUÇÃO}

Os memes são um conjunto de experiências que os usuários de redes sociais digitais "vivenciam" e, para que se compreenda seu significado, é preciso que sejam lidos e interpretados socialmente e culturalmente. Esta prática de leitura e consequentemente de compreensão do meme gera, em muitas circunstâncias uma visão de mundo articulada superficialmente ao humor, mas que nem sempre representa o sentido literal do que se veicula. Produzindo assim, sentidos e significados aos sujeitos que não pertencem àquele contexto, mas que se apropriam do discurso do meme.

Nesta experiência de tradução corriqueira dos memes para compreendê-lo no uso social, o indivíduo que não está inserido no contexto, não é capaz de entender completamente o sentido subliminar ao humor empregado em um determinado conteúdo. É esta experiência que, muitas vezes, nos falta quando não compreendemos uma piada de outro país, e que em algumas situações podem gerar e difundir discursos e opiniões que geram um efeito contrário na realidade.

Um exemplo disso pode ser evidenciado com a participação da atriz Taís Araújo no evento TEDx Brasil, em novembro de (2017, online), no qual ela falou sobre os desafios de criar filhos no Brasil enquanto mãe negra de crianças negras e destacou o impacto da cultura racista vigente no Brasil na vida de seus filhos, e de todas as crianças e adolescentes negros, sua fala então repercutiu na internet:

"Quando ele se tornar adolescente, ele não vai ter a liberdade de ir pra sua escola, pegar uma condução, pegar um ônibus, com seu boné, ou capuz, e seu andar adolescente sem correr o risco de levar uma investida violenta da polícia ao ser confundido com um bandido. No Brasil, a cor do meu filho é a cor que faz com que as pessoas mudem de calçada, escondam suas bolsas e blindem seus carros", disse na palestra" (TEDx, 2017, online).

A partir de então, a reflexão em relação ao preconceito contra a população negra suas formas de manifestação entre a população branca e caminhos para combater essa realidade e transformar o Brasil em um país mais igualitário que propunha a atriz, deu lugar a comentários racistas e a uma impressionante produção 


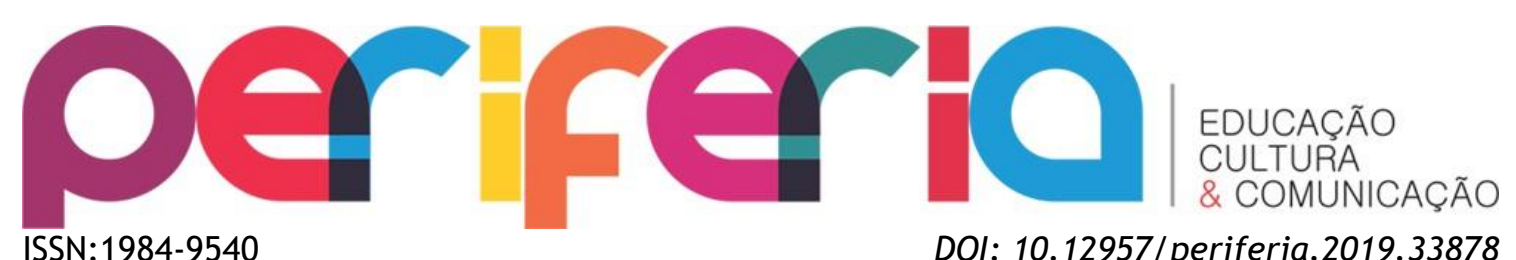

ISSN:1984-9540

DOI: $10.12957 /$ periferia. 2019.33878

e replicação de memes de redes sociais digitais com o discurso irônico contestando a fala dela.

Esse conteúdo foi reproduzido com intensidade e rapidez, resultando em comentários e na intensificação de uma discussão pública nas redes sociais sobre o racismo no Brasil e em contrapartida questionando a própria fala da atriz, ou o seu lugar de fala.

Em virtude disso, de modo mais amplo, neste trabalho nos propomos a discutir a importância dos memes de redes sociais digitais na cibercultura e como eles favorecem a reprodução de discursos racistas e a inserção de diferentes sujeitos em discussões públicas na internet. Para isso, tomamos como objeto o caso dos memes racistas que tencionam o debate sobre racismo, preconceito social e lugar de fala, a partir do episódio da atriz brasileira Taís Araújo no TEDx Brasil em novembro de 2017.

Para Chagas (2016) os memes são ideias que se propagam pela sociedade e por meio de nossas redes sociais digitais sustentam determinados ritos ou padrões culturais. Com isso, nos preocupamos em compreender neste artigo, como estes memes contribuem para a reprodução de um discurso racista das redes sociais, e de que forma? Defendemos o argumento de que a produção memética que reproduz o racismo insere novos usuários no debate público sobre preconceito social e racial no Brasil a partir de uma fala específica que se expande por meio da internet, como é o caso evidenciado neste trabalho. E que permeada pelo humor, pelo deboche e pela sátira do meme, ampliam o contexto e possibilitam uma discussão ética e moral em torno da repercussão nas redes sociais digitais, mas por outro lado também fortalecem a discriminação e o racismo em rede.

0 método utilizado neste artigo foi o da pesquisa qualitativa, de cunho exploratório e descritivo. Este método foi escolhido por se preocupar em investigar a realidade que não é quantificável, que trabalha com o universo de significados, dos motivos, das aspirações, das crenças, dos valores e das atitudes. Deste modo o 


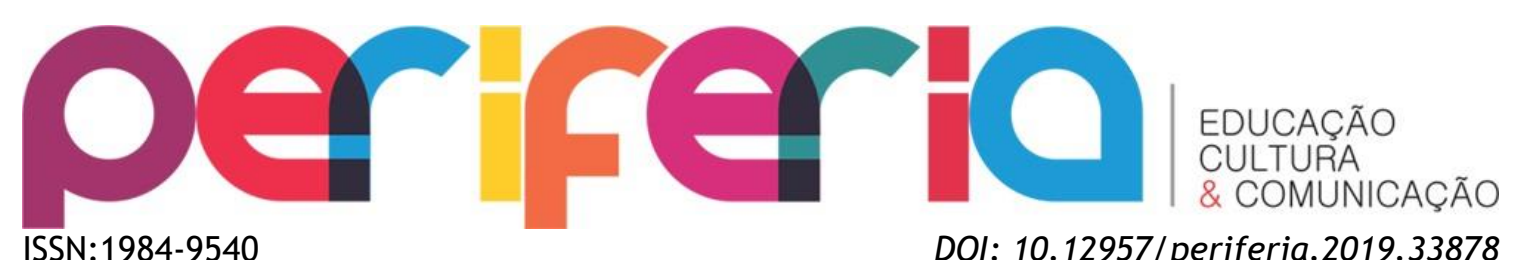

ISSN:1984-9540

DOI: $10.12957 /$ periferia. 2019.33878

texto se estrutura em quatro seções que tencionam o debate sobre produção de sentidos e subjetividades em que se apropria de seu conteúdo.

A primeira seção debate as concepções de preconceito social e racial na cibercultura a partir do contexto brasileiro. A segunda seção problematiza a produção e replicação dos memes racistas sobre a atriz brasileira Taís Araújo e como eles reproduzem o discurso racista e preconceituoso na internet e produzem sentidos e subjetividades em indivíduos que se apropriam. Por fim, discutiremos como estas questões afetam os usuários em rede a partir da inserção deles em discussões públicas efetivada pela apropriação dos memes como linguagem digital que evidencia uma produção de aprendizagens, mas que também reproduzem o preconceito e o ódio por meio das redes sociais digitais.

\section{PRECONCEITO SOCIAL E RACIAL NO BRASIL E LUGAR DE FALA}

Os memes de discussão pública produzidos e compartilhados nas redes sociais após a participação da atriz Taís Araújo no evento TEDx em 2017 mostram um recorte social e cultural sobre o racismo na sociedade brasileira e a maneira como o tema é debatido pelos indivíduos que estão inseridos nela. Não obstante, também mostra o modo como este assunto é veiculado na internet e especialmente nas redes sociais digitais.

Inúmeros praticantes das redes sociais se engajaram na discussão e, através dos memes, repercutiram a fala da atriz expondo por meio do humor "memético", debochado e crítico seu ponto de vista sobre o assunto, ou tendo como alvo a atriz, uma importante voz do ativismo negro no Brasil. A discussão, nitidamente caracterizou-se por uma polarização pró e contra o discurso da atriz.

0 grupo favorável à atriz enalteceu o seu discurso e a importância dele para o movimento negro, nas publicações via Twitter. Já os usuários que discordaram, trataram o discurso com desdém e deboche, e evidenciaram uma suposta "vitimização" da atriz, questionaram inclusive seu próprio lugar de fala. Ou seja, afirmaram por meio da rede, que para a atriz, sendo uma figura pública seria fácil e 


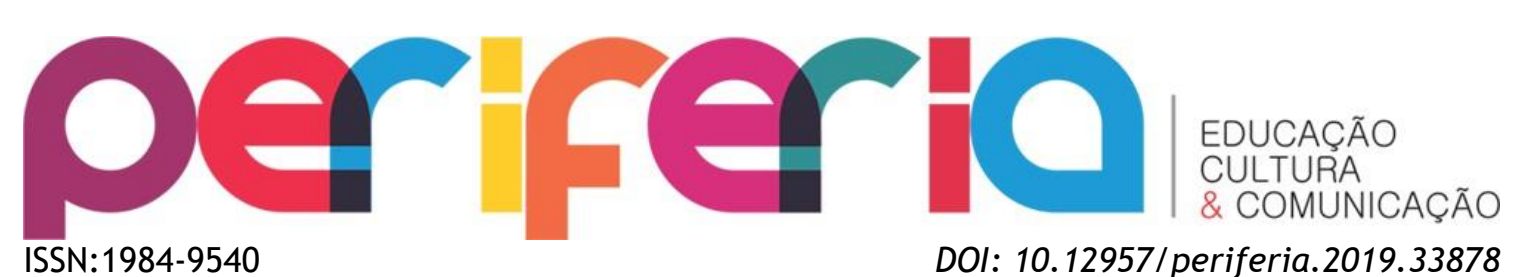

ISSN:1984-9540

DOI: $10.12957 /$ periferia. 2019.33878

simples se portar daquela forma para se promover publicamente, evidenciado uma fala supostamente vitimista.

É importante destacar que o próprio conceito de lugar de fala que aparece com frequência em conversas e debates entre militantes de grupos e movimentos sociais distintos, nem sempre é debatido ou discutido da forma que é proposto academicamente. 0 conceito representa, para algumas pessoas, a busca pelo fim da mediação ou intermediação em um debate ou discussão pública: a pessoa que sofre preconceito fala por si, como protagonista da própria luta.

Entretanto, o conceito de lugar de fala vem sendo distorcido, evidentemente não para garantir a fala em espaços democráticos de grupos socialmente excluídos, mas para proibir a fala de outros grupos. E embora seja razoável que um grupo oprimido escolha não ouvir o grupo opressor em nenhuma ocasião, dizer que é por conta do "lugar de fala" é desconhecimento. Evidente que a maneira como o conceito é aplicado no debate público das redes sociais atualmente é superficial e incompleta, o que leva a equívocos em sua aplicação.

Deste modo, quando a atriz utiliza seu lugar de fala para expor sua opinião sobre o racismo, ela não limita diferentes grupos de uma possível inserção no debate. Mas fica nítido que as dificuldades sociais impostas aos negros foram evidentemente compreendidas no discurso para uns interlocutores da rede, porém, inexistente e incompreensível, até intolerável para outros, como demonstra a popularidade dos memes que ridicularizaram a fala da atriz e que abordaremos a seguir.

A disparidade das interpretações sobre a fala reproduzidas pela replicação de memes nas redes sociais demonstra como a questão racial e o preconceito social são debatidos no Brasil, de modo superficial e intolerante e implicados pela construção de piadas ácidas. De tal modo, constatamos aqui que o memes enquanto unidades de conteúdo digital com características comuns, criadas com consciência mútua e colaborativa, imitadas e transformadas pela internet por usuários, dão possibilidades de criar também, novas experiências de aprendizagens, mesmo que de modo informal e independente e inserida em uma visão preconceituosa. Por meio da 




ISSN:1984-9540

DOI: $10.12957 /$ periferia.2019.33878

intertextualidade, da produção de discursos, da autoria visual, do uso da linguagem digital, permeada por uma pedagogia das imagens culturais da cibercultura.

\section{OS MEMES DA TAÍS ARAÚJO E A PRODUÇÃO DISCURSIVA}

A mensagem contida em um meme, para além do humor implícito representa uma ideologia, que por sua vez, indica aspectos sociais e culturais dos usuários e das páginas onde ele é replicado. Entretanto, quando tratamos de memes é paradoxal discuti-lo apenas a partir da noção de cultura auto-reprodutora ou viral, uma vez que assim como Jenkins (2014) entendemos que a própria cultura é um produto humano e que só se reproduz por meio de expediente humano. Ou seja, articulada a um contexto específico.

Por outro lado, a ressignificação de uma imagem em um meme, por exemplo, e sua subversão de contexto sob a ótica da cultura participativa podem ser consideradas como formas de produção discursiva em busca de reputação e popularidade dos atores sociais na rede, articulados a produção e replicação de conteúdos digitais. Portanto, o gênero meme, aqui estudado não se limita apenas ao resultado de um evento tecnológico da cultura digital, mas é entendido como uma expressão, linguagem, fenômeno de comunicação; que carrega novas potencialidades de letramentos e novas possibilidades de aprendizagens por meio de sua carga discursiva e seus significados nos usuários implicados na internet.

As diferentes reações produzidas pelos memes, ou especialmente no que se refere ao discurso da atriz Taís Araújo aqui debatidos neste texto, levam a uma reflexão a respeito do preconceito social e racial no Brasil e que questionam o lugar de fala do negro na sociedade, ou fazem pensar sobre como isso é abordado e debatido nas redes sociais digitais.

Por meio da análise das postagens sobre o assunto no Facebook, Instagram e Twitter, sobre a repercussão do discurso da atriz, evidenciam o que acontece quando o debate público se limita a superficialidade dos fatos ou quando não estão articulados adequadamente ao que foi dito ou veiculado em um determinado evento 


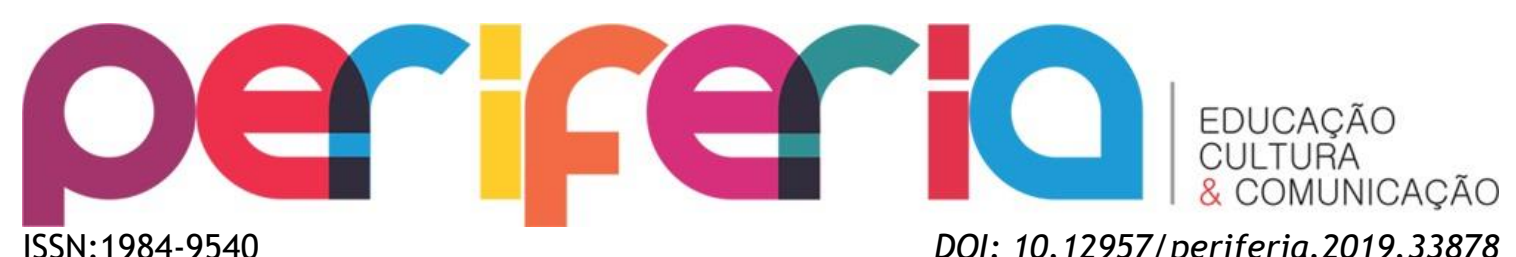

ISSN:1984-9540

DOI: $10.12957 /$ periferia. 2019.33878

ou situação, mas tomam repercussão e destoam o sentido na produção comunicativa das redes sócias afetando inclusive o debate de cunho ético e moral.

$\mathrm{Na}$ análise das postagens sobre $\mathrm{o}$ assunto nas redes sociais citadas anteriormente, evidenciam pela avaliação dos comentários e pelo nível do debate na rede, quatro grupos identitários distintos, caracterizados pelo engajamento coletivo na discussão com argumentos ideológicos semelhantes entre si, que reproduzem o interesse próprio ou uma visão de mundo comum na rede social.

O primeiro grupo caracterizado por pessoas que concordam com a atriz e rechaçaram os memes que a criticaram, por meio de postagens de apoio, taxando os seus criadores de racistas, esse grupo centrou-se na produção de argumentos defensivos à atriz e a importância do movimento negro.

O segundo grupo, composto por usuários que debocham do discurso da atriz e o trataram como um discurso "vitimista”, uma vez que a atriz é bem sucedida e faz parte da "elite brasileira”, mesmo sendo negra, ou seja, não tem que lidar com o preconceito cotidiano da mesma forma que os negros pobres. Um terceiro grupo com características semelhantes, composto aparentemente por negros, e ativistas, que não consideram que a atriz possua legitimidade para falar sobre preconceito, uma vez que ela faz parte da elite e não lida com o racismo da mesma maneira que os negros menos abastados.

Por último o quarto grupo, constituído por usuários das redes sociais que negam a existência do racismo na sociedade brasileira ao passo que discordam do discurso da atriz em tom de deboche. Esse grupo, caracterizado pelo tipo de discurso e argumentos, mostrou ser o mais popular e mais ativo nas discussões a respeito da questão, e o mais engajado na produção e replicação de memes, dos mais diversos tipos e formatos, como evidenciaremos a seguir com memes em formatos de imagens que foram mais populares nas redes sociais avaliadas. 


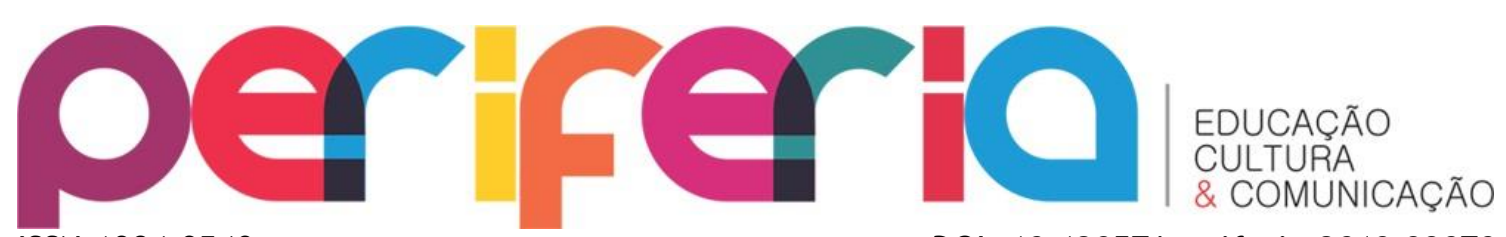

ISSN:1984-9540

DOI: $10.12957 /$ periferia. 2019.33878

\subsection{Dos memes e seus sentidos em rede}

No primeiro meme (Figura 1), amplamente compartilhada é utilizado o anime japonês Naruto para repercutir a fala da Atriz. Na imagem, Naruto, o personagem, se vê obrigado a fugir diante de um possível encontro com os filhos da atriz. 0 meme objetiva reforçar a interpretação vitimista sobre o discurso da atriz por meio da fuga de um personagem de mangá, que não é possível de encontrar por se tratar de um ser da ficção. Entretanto, evidencia a necessidade de fuga que remete diretamente a fala da atriz.

A adaptação de um mangá do Naruto em animação japonesa foi exibida na TV brasileira nos canais SBT e Cartoon Network e teve uma grande popularidade entre os jovens. A produção deste meme, associando a imagem do Naruto, um ser dotado de poderes e especialidades sobrenaturais com a fala da atriz representa a irrelevância que os usuários que replicaram a imagem dão ao discurso e a fala da atriz sobre o racismo, ou a sátira sobre "mudar de calçada" ou fugir dos filhos da atriz.

Figura 1: Naruto

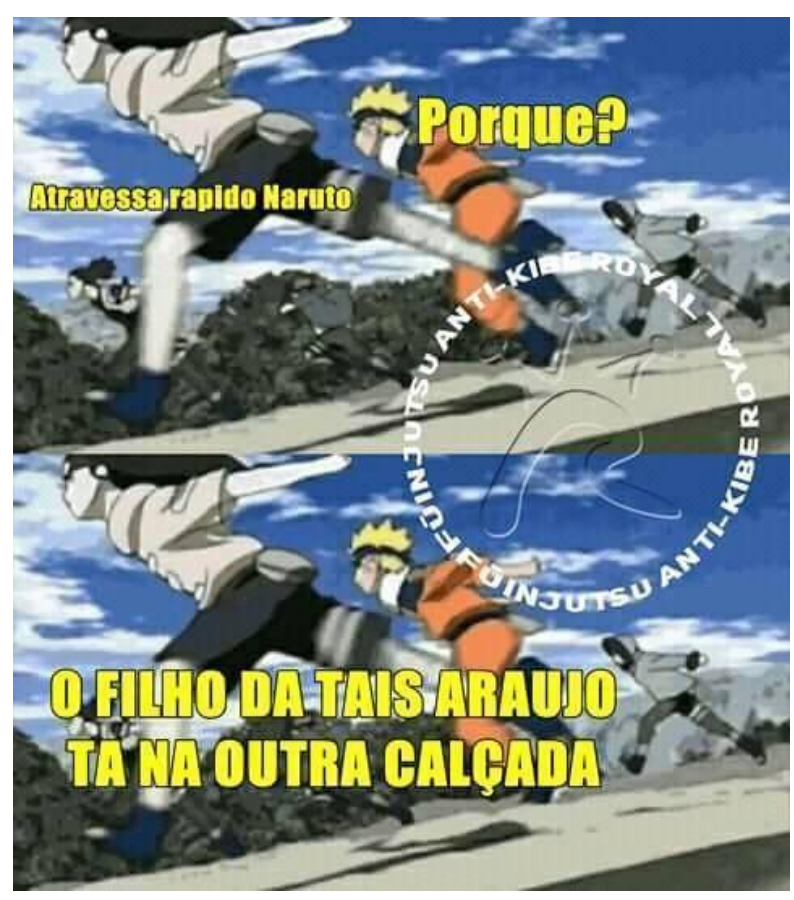

Fonte: Twitter 


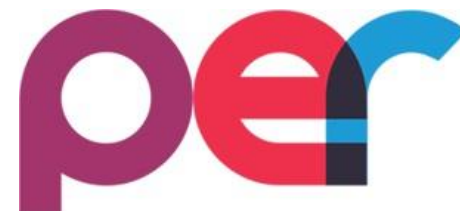

ISSN:1984-9540

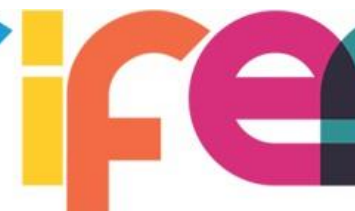

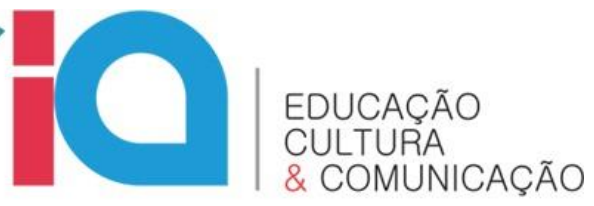

DOI: $10.12957 /$ periferia.2019.33878

0 meme da figura 2 produz o discurso imagético com a temática esportiva que reproduz intertextualmente uma interpretação da fala de Taís sem legendas. A imagem mostra a disputa olímpica dos $100 \mathrm{~m}$ rasos, liderada por Usain Bolt, jamaicano que é um dos homens mais rápidos do mundo. 0 meme mostra que ele está "correndo" supostamente da atriz e dos seus filhos, por conta do enorme grau de periculosidade que eles supostamente apresentam. Mais uma vez, o meme produz além do humor ácido, uma interpretação "vitimista" sobre a fala da atriz defendida e repercutida amplamente nas redes sociais e remete à necessidade de fuga e distanciamento dos filhos da atriz.

Figura 2: Usain Bolt em fuga

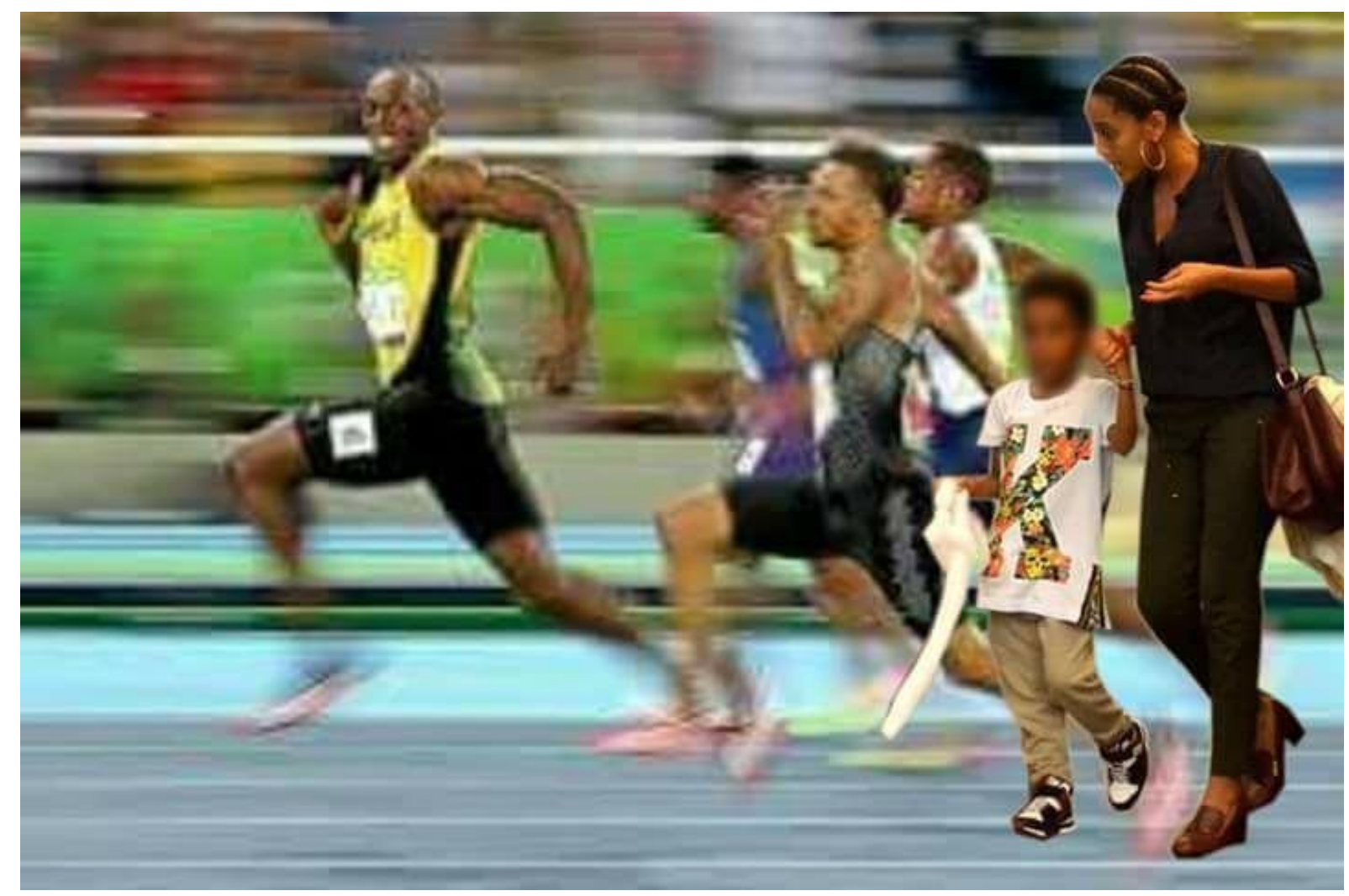

Fonte: Twitter

No meme da figura 3 é utilizada duas imagens da Rua 25 de março, localizada em São Paulo, que é um dos locais mais populares e mais movimentados na cidade e do Brasil. 0 autor do meme utiliza dessa notoriedade pública a respeito da 


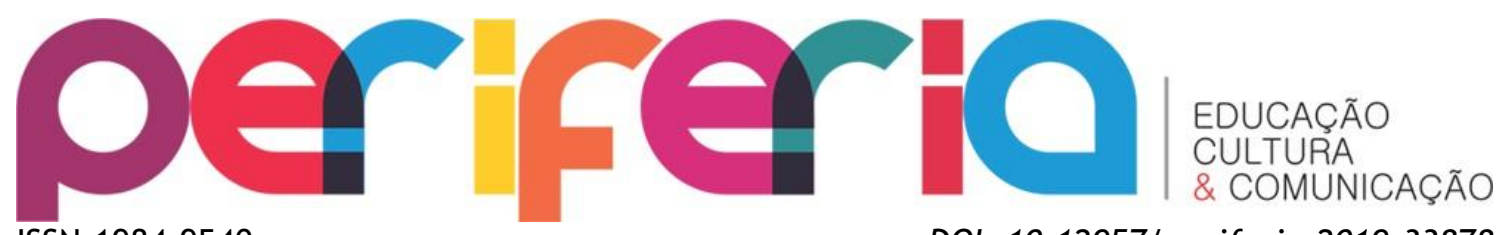

ISSN:1984-9540

DOI: $10.12957 /$ periferia. 2019.33878

popularidade do local e do grande movimento, para mostrá-lo esvaziado com a presença da atriz e do seu filho. Mais uma replicação que evidencia pela intertextualidade discursiva a interpretação do seu criador em rede a respeito do comentário da atriz e que também produz outras traduções e significados nas redes sociais, como a opção de fuga das pessoas, o distanciamento, o medo.

Figura 3: Rua 25 de março, São Paulo.

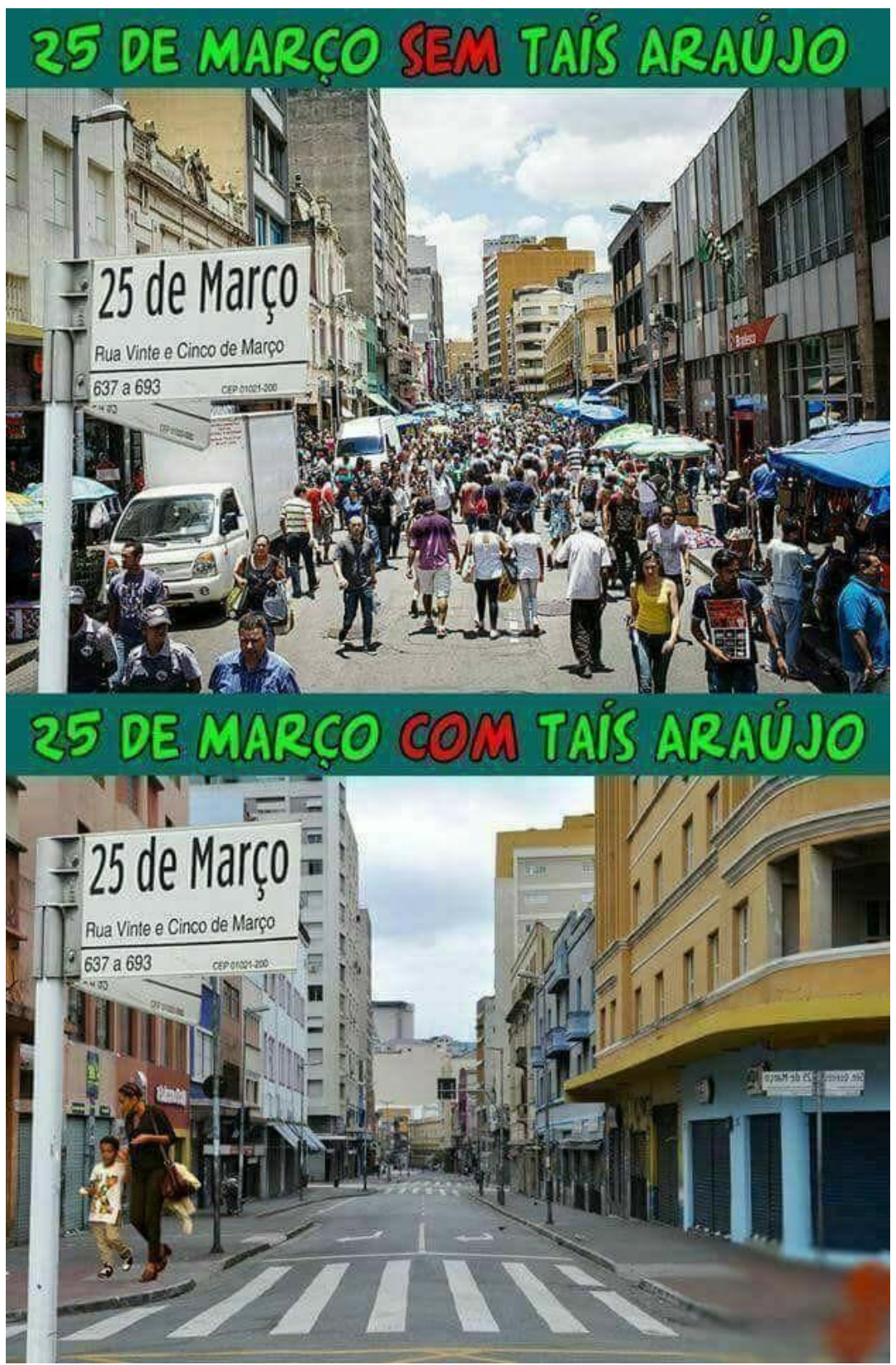

Fonte: Twitter 




ISSN:1984-9540

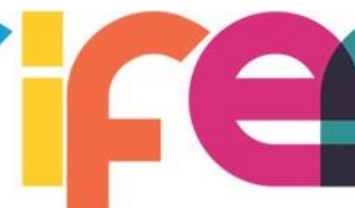

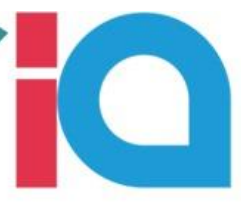

EDUCAC̄̃̃

CULTURA

\& COMUNICAÇÃO

DOI: $10.12957 /$ periferia. 2019.33878

$\mathrm{Na}$ figura 4, a produção do meme utiliza uma famosa imagem que estampa a capa do álbum "Abbey Road”, da banda inglesa "Beatles”, uma das bandas mais populares da história da música e um grande símbolo da cultura ocidental. 0 autor do meme apela para o elemento cultural como forma de demonstrar a sua interpretação da fala da atriz. A capa do álbum é caracterizada pelos quatro integrantes da banda ao atravessar a rua. Mas na produção dos memes em rede este evento associado aos elementos do discurso da atriz remetem à fuga dos Beatles à um possível encontro com o filho da atriz brasileira.

Figura 4: Beatles

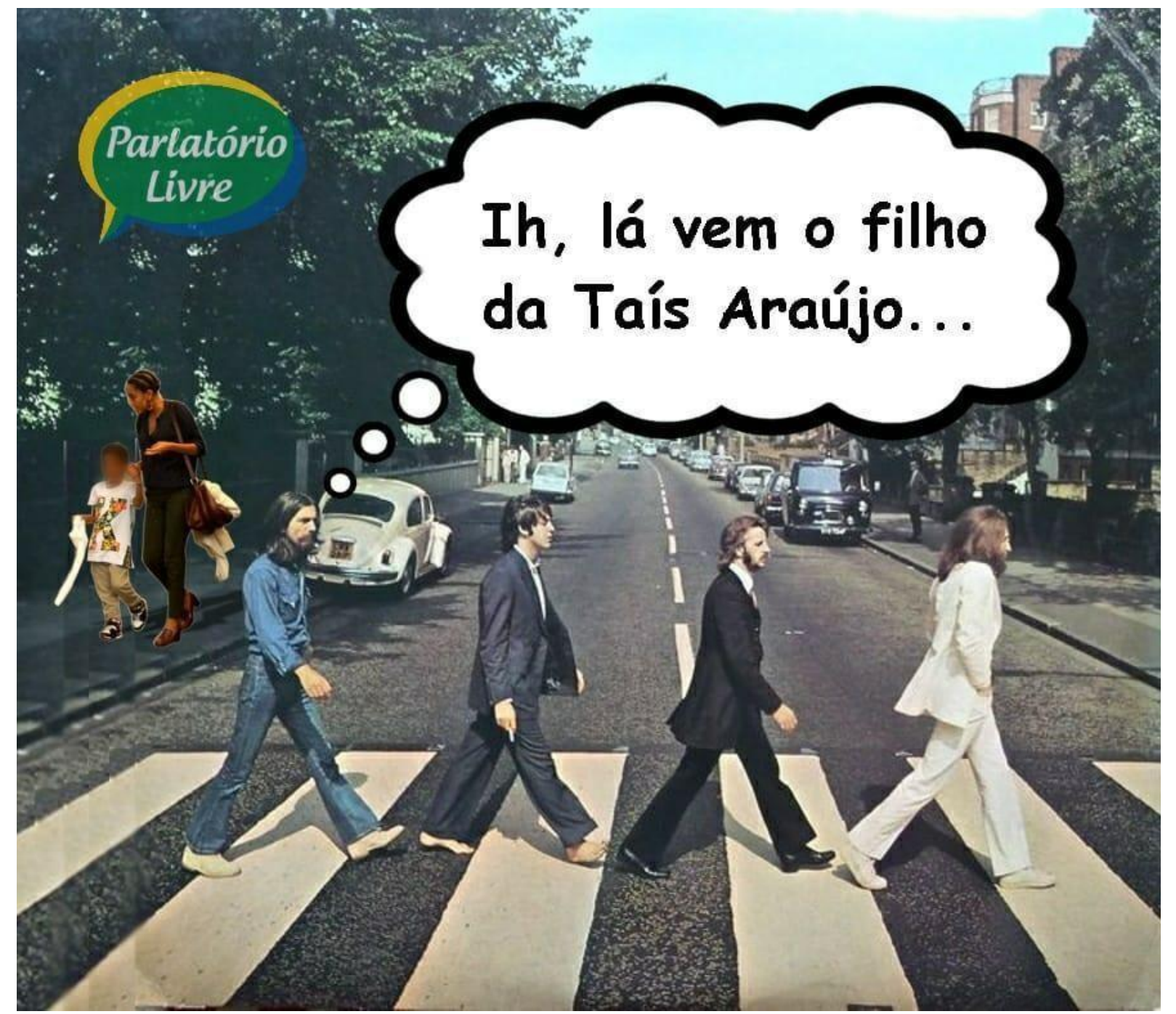

Fonte: Facebook 


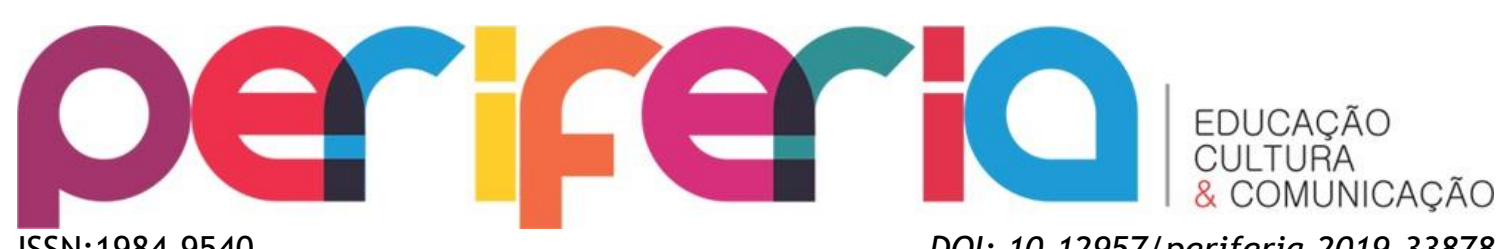

ISSN:1984-9540

DOI: $10.12957 /$ periferia. 2019.33878

Na Figura 5, o meme utiliza uma imagem da atriz, seu filho e o marido na praia e banhistas "andando" na água como forma de fugir do encontro da atriz. A montagem, bem elementar e grotesca com legendas e junção de imagens, aumenta a acidez da mensagem do meme e consequentemente, o tom jocoso em relação à fala dela. A tradução e interpretação do meme remete mais uma vez à fuga dos personagens e distanciamento como a um possível afogamento, por ser preferível entrar nas aguas do mar ao encontrar com a atriz e os filhos.

Figura 5: Taís Araújo e família na praia
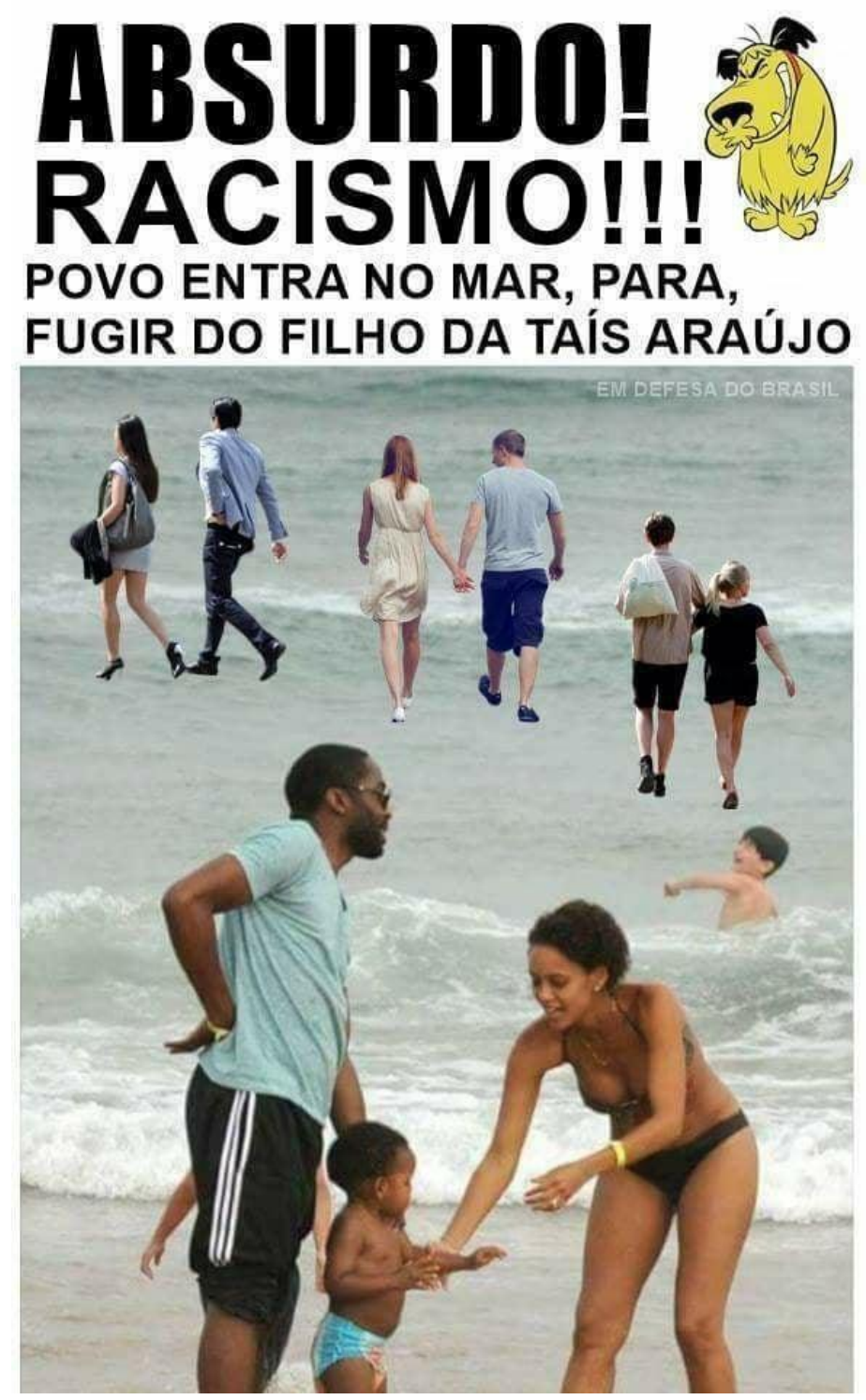

Fonte: Twitter 




Em mais um meme, exposto na figura 6, utiliza o paraquedismo como suporte da sua ideia para a construção semiótica da mensagem associada as legendas. A imagem mostra o homem saltando de um avião e a frase revela o motivo e o tom da piada implícita. $O$ ato e a coragem de saltar de um avião são os elementos utilizados para o entendimento do seu ponto de vista que remete mais uma vez à uma suposta fuga da Taís e do seus filhos.

Figura 6: Salto de paraquedas

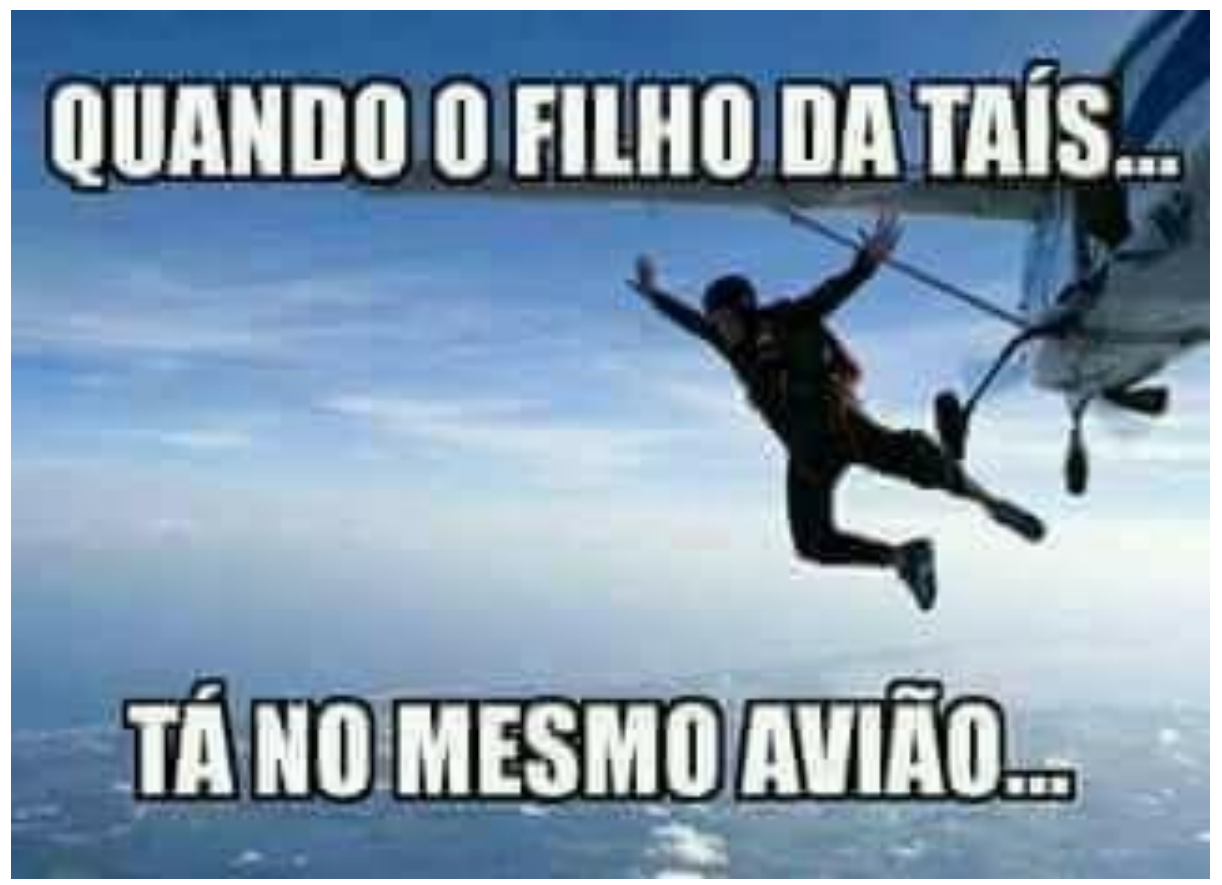

Fonte: Google imagens

Nesse meme, a imagem de um homem espionando através de uma persiana é o objeto utilizado pelo autor para reforçar a sua opinião a respeito da fala da atriz no Facebook. A postagem produz dois tipos de interpretações visualmente: o medo em que o personagem da imagem tem de um possível encontro com os filhos da atriz; e a fuga e o distanciamento. 




Figura 7: Olhando pela janela

Luiz Flávio Ramos Brigagão O filho da Tais Araújo já foi embora?



Fonte: Facebook

Assim, entendemos que a produção e compartilhamento deste tipo de meme, para além do humor, também reproduzem preconceito, ódio e o fortalecimento da produção de discursos polarizados em rede. Uma vez que cada produção simbólica e imagética produz uma série de sentidos, significados e interpretações distintas entre usuários de redes sociais digitais. Com isso, entendemos também que para além da sátira implícita, este tipo de conteúdo também produz uma série de aprendizagens já que leva ao debate público questões como preconceito racial, social e lugar de fala e também a formação de uma impressão equivocada do episódio referido.

\section{POR QUE OS MEMES IMPORTAM?}

Nos memes em formatos de imagens descritos anteriormente, é possível verificar que o humor é veiculado no conteúdo associando ao episódio da atriz Taís Araújo em sua fala no TEDx, com alguma situação curiosa em questão. No entanto, o que queremos chamar atenção é que cada uma das replicações dos memes aqui apresentados evidenciam também uma relação entre a fala da atriz sobre seus filhos e a reação dos sujeitos que compõem a semiótica da imagem de cada meme, enfatizando respectivamente, medo, distanciamento e a tentativa de fuga. 


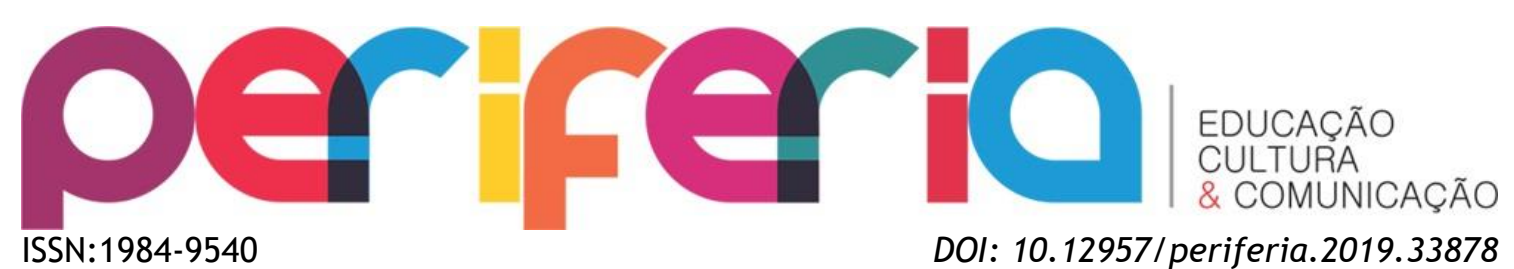

Com este trabalho, nos propomos a argumentar sobre a produção discursiva dos memes em redes sociais digitais e evidenciar que mesmo com o humor implícito eles fortalecem o racismo na rede como evidenciamos aqui. Como a veiculação de conteúdo racista e preconceituoso que produzem sentidos e subjetividades nos usuários de redes sociais, que se apropriam e até produzem seu próprio conteúdo ou sua impressão a partir dos memes.

Com isso é preciso enfatizar que consideramos como memes as produções de conteúdos nas redes sociais a respeito da fala da atriz Taís Araújo, por que a temática gerou polêmica em larga escala, promovendo o debate sobre o tema e com isso ganhou notoriedade em rede, mesmo que apenas pela intenção de gerar humor em diversos formatos do hipertexto. A partir da polêmica gerada, os usuários das redes sociais puderam replicar e compartilhar sua opinião e se engajar no debate em rede. O que é característico da cultura da conexão, como propõe Jenkins (2014).

Deste modo, considerando que o que caracteriza um meme não é apenas o formato, mas como o conteúdo é replicado pelos sujeitos implicados nas rede e articulado à novos contexto e eventos, podemos concluir que a polêmica sobre a Atriz se constituiu como terreno fértil para a produção "memeal", e que fortaleceram o preconceito racial em rede e o separatismo promovido pela promoção de discursos polarizados. Posto que um meme não é somente fruto da dialética entre imitação e inovação, mas um conjunto de elementos que só são entendidos se lidos e interpretados socialmente.

Nas redes sociais e nos ambientes digitais em rede, os usuários aproveitam da criatividade, coletivismo e da produção colaborativa de outros praticantes culturais. Com isso, também os implicam como fonte de reprodução de subjetividades e sentidos que nem sempre permitem a interpretação real dos fatos, mas que em contrapartida estão engajados a "inteligência coletiva" a partir de uma rede de sujeitos engajados em ambientes formativos com audiências diversas presentes em rede.

Os memes aqui debatidos representam um recorte social muito pertinente do ambiente e de características dos usuários e como propagam conteúdo em rede. Entender a propagação de discursos preconceituosos e “involuntários” em rede, por 


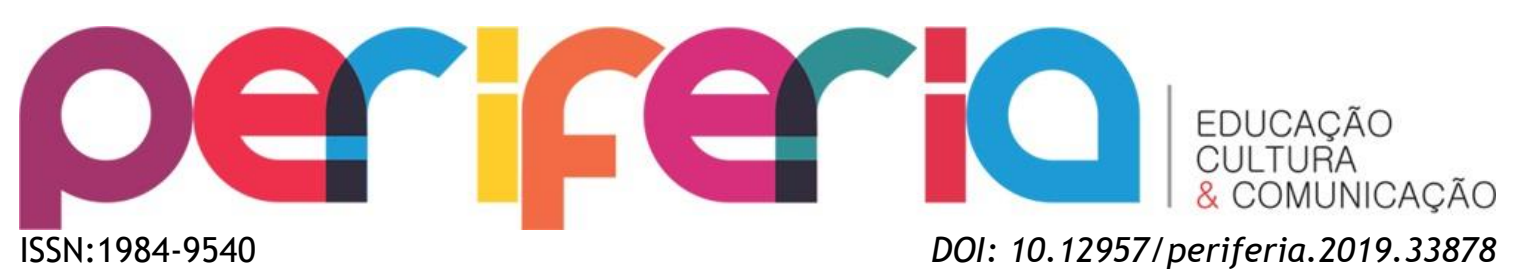

meio do compartilhamento e propagação de um meme, talvez configure um erro crasso, visto que todo meme possui representação e carga ideológica e toda linguagem carrega consigo sentidos e significados. Posto que a interação entre os usuários é potencializada pela interface da rede e elementos virais como os memes são fundamentais para a consolidação das redes como uma comunidade digital, onde as pessoas têm voz ativa em conexão.

Isso significa que a retórica contida nos discursos públicos que permeiam as redes sociais e os memes representam muito mais do que uma simples propagação passiva de uma imagem ou vídeo na rede, significa produção de sentido, significados, impressões sobre determinado contexto e convívio em rede, já que os membros de uma audiência na rede são praticantes culturais e participantes ativos na construção de aprendizagens em rede sociais.

Deste modo, os memes que reproduzem discursos racistas a respeito do lugar de fala da atriz Taís Araújo, atrelado pelo hipertexto à questões como medo, distanciamento e necessidade de fuga, também produzem educações e aprendizagens aos indivíduos que não pertencem diretamente àquele contexto, mas se apropriam dele. Neste caso, o impacto das mensagens veiculadas pela linguagem dos memes são sempre ampliadas e expandidas pela capacidade de seu movimento na rede entre pessoas e entre comunidades na internet e com isso a repercussão de determinado conteúdo pode gerar o efeito contrário.

Quem participa desse processo de replicação em rede quer sempre aumentar a sua audiência e ter uma "reputação online". Esse desejo estimula a sua participação no debate e uma retórica acalorada diante de qualquer discussão é uma maneira eficaz de validar esse processo. A propagação de um conteúdo dentro de uma comunidade para outra demonstra o desejo na circulação dessa mensagem. Logo, a mensagem não pode ser desprezada, especialmente, quando se torna tão popular (JENKINS, 2014).

Pesquisar nossas relações sociais por meio de redes sociais digitais, é tarefa das mais complicadas. Entendê-la a partir dos memes, é olhar para os elementos que the conferem rastros, expressões e alguma materialidade em rede. Assim, entender os memes como irrelevantes ou como "modas" e que não levam a nada é enviesar o 


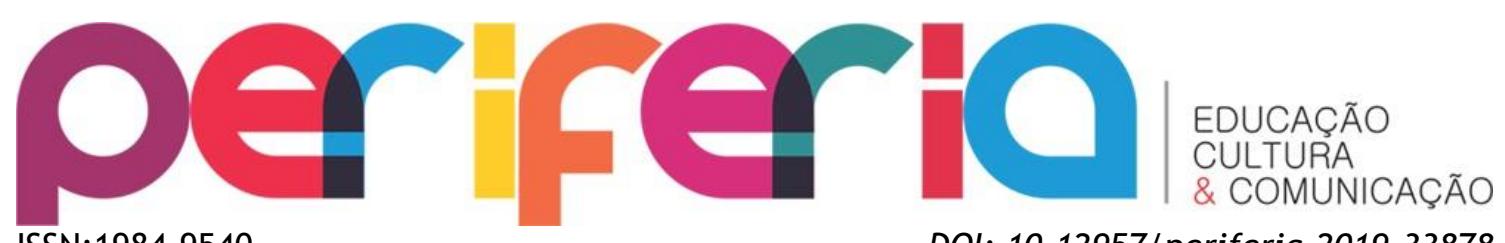

olhar pelo curto prazo. Um olhar que não combina com a cultura popular dos memes de redes sociais digitais.

Com isso, podemos concluir que de fato a produção de memes sobre a fala da Taís Araújo no TEDx Brasil em 2017, onde afirma que "a cor do seu filho faz com que as pessoas mudem de lado na rua e segurem suas bolsas", se mostra como uma produção racista e que incentiva produções e opiniões racistas em redes sociais, visto que os memes avaliados sempre associam os elementos das imagens em relação à atriz e dos filhos a uma ação de distanciamento e fuga, mesmo que com pretensa carga humorística.

\section{REFERÊNCIAS}

CHAGAS, Viktor. Memes, engajamento político e ação coletiva, ou Por que o "vomitaço" importa? Disponível em: http://www.museudememes.com.br/memesengajamento-politico-e-acao-coletiva-vomitaco-1/ Acesso em: 11 abr. 2016.

JENKINS, H. Cultura da Convergência. Tradução: Susana Alexandria. 2. ed. São Paulo: Aleph, 2009.

SHIFMAN, Limor. Memes in digital culture. Massachusetts: MIT Press, 2014.

SOUZA, Carlos Fabiano de. Memes: formações discursivas que ecoam no ciberespaço. VÉRTICES, Campos dos Goytacazes, volume 15, n 1, p. 127-148, janeiro a abril de 2013 